\title{
Overcoming the Challenges of Women in Politics: Lesson for and from Nigeria DOI: 10.36108/NJSA/6102/14(0190)
}

\author{
Tayo O. George* \\ Christiana Adetunde \\ Oluwakemi Ijagbemi \\ Mercy Udume \\ Department of Sociology \\ Covenant University, Ota, Nigeria
}

Corresponding Author: email: tayo.george@covenantuniversity.edu.ng*

\begin{abstract}
In spite of the fact that women constitute over 50\% of the registered voters in the country and are actively involved in political rallies and election campaigns, they are grossly underrepresented in elective and leadership positions in political parties and other sectors of the nation's economy. The paper examines the historical antecedents of women in politics. It identifies women's participation and contributions to Nigeria's political and democratic process between 1999 and 2015 with a view to identifying the major challenges and possible means of overcoming the issues. Relying mainly on secondary sources of data, the paper engages archival review of existing gender policies and their roles in promoting women's political participation or otherwise. The paper concludes that with greater awareness, enabling environment, better political commitment and policies, women's political participation in Nigeria will improve markedly.
\end{abstract}

Keywords: women, political participation, democratic process, gender policies, Nigeria

\section{Introduction}

Women all over the world are in one way or another discriminated against and/or marginalized. This is evident in their representation in all sectors of the global economy. There are however, different levels of this underrepresentation and/or discrimination around the world. In Nigeria, women experience enormous economic, social, educational, religious and political discrimination as shown in the subsections of the paper. In Politics, Nigerian women are grossly under represented and dominated by men; despite the fact that women constitute about $60 \%$ of the registered voters in the country and are also active participants in political rallies and campaigns across the nation (Irabor, 2011). Few women vie for political offices and fewer of these win elective seats. When it comes to vying for elective positions, they are discriminated against and dominated by men.

Redefining the role of Nigerian women in the Nigerian political life is very essential, infact it was the focus of a conference held for female political 
leaders at the national and local levels from the six leading political parties and women legislators in the National Assembly. It aimed at enabling women to occupy positions of leadership within political parties, to be more strategic and effective within those roles, and to raise the profile of Nigerian women as an important voting bloc (Women's Democracy Network) in collaboration with the International Republican Institute (IRI, 2012). In Nigeria, awareness about the role of women in political development gained momentum in the latter half of the "1980s (Omu \& Makinwa, 2008). Awareness was further enhanced in 1995 as a result of the effective participation of Nigerian women in the International Conference on Women in Beijing, China which facilitated more participation of women in Nigerian politics.

Female political office holders are crucial for reasons that surpass their individual interests. It is particularly crucial to have women in elective posts where decisions are made for the following reasons:

I. According to Nigeria Gender Report (2008), a fair representation of women in elective positions at the local, state and national levels helps to eliminate the under representation of women in politics. This, in turn helps to address areas of concern for women's welfare and some other social issues that concern the whole society. This is provided women have been able to attain the critical mass that could make them to be at the least, a minority where important decisions are being made.

II. Their presence in decision-making at all levels of governance could enhance equal allocation and sharing of important resources between the sexes. According to the same gender report referred to earlier, a well and equally allocated resources lead to a higher human development in a country. The report argues that this is obviously true because women tend to focus on areas of social concern such as children's education, health and social services (Miranda, 2005). It also argues that there is a difference in the way women and men allocate resources when vested with power to do so.

III. Soraya (2012) asserts that women give more attention to issues of cooperation than men. This represents a sense of team spirit towards achieving progress. According to Cheng (2014), women possess a different method of governance from men; the former's method helps to achieve results through cooperation, empathy and concern for the less privileged. This reduces conflict in the society.

IV. With reference to a study carried out by Dollar, David, Fisman, Raymond and Gatti in 1999, Cheng (2014) opines that women leaders are less corrupt than their male counterparts.

This paper therefore seeks to examine the way out of the present situation by examining the steps taken by other countries around the world in tackling the poor representation of women in Politics and by extension, in elective seats. However, the challenges facing women politically and the benefits of having women adequately represented in elective positions shall be discussed briefly. 
Emphasis shall be on overcoming the challenges that undermine equal representation on elective seats in the country.

\section{Womens' Political activities in the Pre-Colonial Era}

During the pre-colonial era, Nigerian women contributed to the sustenance of the kin group. Pre-colonial Nigerian economy was basically at a subsistence level, and Nigerian women participated effectively in this economy. Apart from being mothers and wives and taking charge of the domestic sector, women contributed substantially to the production and distribution of goods and services.

In the agricultural sector, women farmed alongside their husbands and children. In south eastern Nigeria, women also took part in the production of palm oil and palm kernel. They in addition participated in local and long distance trade in different parts of Nigeria and were fully involved in the procurement and sale of various food items and related commodities.

Women in pre-colonial Nigeria were fully involved in food processing such as fish drying (especially in the coastal areas of Calabar, Oron and the Niger Delta area), garri processing etc. In eastern Nigeria, the women of Okposi, Uburu and Yala were very active in salt production (Ola, 2008).

Women were engaged in pottery making, especially in Afikpo in present day Abia State, and in weaving. In northern Nigeria, even the women in purdah - a system whereby women were secluded from the public, or separated from men and covered their faces and bodies when they are near men (MerriamWebster Dictionary, 2014) - were involved in food processing and also traded with the aid of their children. Most often, these women supplied the means of sustenance for entire households.

Education in pre-colonial times was functional. It enabled women to obtain a skill in order to earn a living. a woman who was without a craft or trade, or who was totally dependent on her husband, was not only rare, but was treated with contempt (Aliyu, 2009). As regards politics, women in pre-colonial Nigeria were an integral part of the political set up of their communities. Most often, they carried out separate functions from the men. These functions were fully complementary. In pre-colonial Bomu, for instance, women played active parts in the administration of the state. They held very important offices in the royal family, including the offices of the Megira (the Queen mother) and the Gumsu (the first wife of the Mai or King) (Ola, 2008).

Women also played a very significant role in the political history of ancient Zaria. The modern city of Zaria was founded in the first half of the 16th century, by a woman called Queen Bakwa Turuku. She had a daughter called Amina who later succeeded her as Queen. Queen Amina was a great and powerful warrior. She built a high wall around Zaria in order to protect the city from invasion and extended the boundaries of her territory beyond Bauchi. The 
people of Kano and Katsina paid tributes to her. She turned Zaria into a very prominent commercial centre.

Same obtained in ancient Yoruba land. The Oba ruled with the assistance of a number of women referred to as the ladies of the palace. The ladies of the palace consisted of eight titled ladies of the highest rank. The significant role played by prominent women such as Moremi of 1fe, Emotan of Benin and Omu Okwel of Ossomari in the pre-colonial history of Nigeria cannot be ignored. Moremi and Emotan were great amazons who displayed tremendous bravery and strength in the politics of lfe and Benin respectively, while Omu Okwei dominated the commercial scene of Ossomari in present day Delta State (Omu and Makinwa, 2006).

\section{The Colonial Period}

When it came to politics, colonialism affected Nigerian women adversely as they were denied the franchise and very few of them were offered any political or administrative appointments. For instance, it was only during the 1950s that three women were appointed into the House of Chiefs, namely Chief (Mrs.) Olufunmilayo Ransome Kuti (appointed into the Western Nigeria House of Chiefs); Chiefs (Mrs) Margaret Ekpo and Janet Mokelu (both appointed into the Eastern Nigeria House of Chiefs). It was also only in the 1950s that women in Southern Nigeria were given the franchise. The women's wings of political parties possessed very little functional relevance (Ola, 2008).

In 1929, thousands of southeastern Nigerian women handed the British colonial administration its first major challenge when they organized a massive revolt against taxation policies imposed on market women. Gathering in large numbers at various administrative offices, the women questioned the new tax laws and confronted the corrupt "warrant chiefs" that had been appointed to serve as local agents of the British through the system of indirect rule. Effectively using song and dance as vehicles of ridicule and denunciation, they forced some of the chiefs to resign (Dike \& Chike, 1995). As the protests gathered momentum, the women became more aggressive, attacking and looting European owned stores and banks as well as native courts managed by British officials, some of which they burned to the ground. The colonial police were eventually called in to intervene and fired shots into the crowds, killing several women. It is estimated that about 25,000 women participated in this revolt, which compelled colonial authorities to revoke their intended imposition of taxes and to significantly clip the powers of the warrant chiefs (Ekine, 2013).

\section{The Post-Colonial Period}

The role of women in Nigeria's post1960 politics has not been reflected sufficiently, in terms of appointments to policy making posts, in spite of massive support given to various political parties by women, women organizations, market women movements etc., until recently, very few women benefited from political patronage. In Southern Nigeria, women already had 
the franchise by 1960; thus in that same year, Mrs. Wuraola Esan from Western Nigeria became the first female member of the Federal Parliament. In 1961, Chief (Mrs.) Margaret Ekpo contested elections in Aba Urban North constituency under the National Council of Nigerian Citizens (NCNC) platform and won, becoming a member of the Eastern Nigeria House of Assembly until 1966; Mrs. Janet N. Mokelu and Miss Ekpo A. Young also contested elections, won and became members of the Eastern House of Assembly.

In northern Nigeria, however, women were still denied the franchise even after independence. As a result, prominent female politicians like Hajia Qambo Sawaba in the North could not vote neither could she be voted for. It was only in 1979 that women in northern Nigeria were given the franchise, following the return to civilian politics. The reason for this is rooted in cultural and religious practices that discourage women from participating in public activities.

\section{The Second Republic (1979-1983)}

During the Second Republic (19791983), there was further progress. A few Nigerian women won elections into the House of Representatives at the national level. Some of these women were Mrs. J.C. Eze of the Nigerian People's Party (NPP) who represented Uzo Uwani constituency in former Anambra State, Mrs. V.O. Nnaji, also of NPP who represented lsu and Mrs Abiola Babatope of the Unity Party of Nigeria (UPN) who represented Mushin Central II of Lagos State. But, on the whole, very few women won elections into the State Houses of Assembly during the Second Republic.

During the same period, only two women were appointed Federal ministers. They were Chief (Mrs.) Janet Akinrinade who was Minister for Internal Affairs and Mrs. Adenike Ebun Oyagbola, Minister for National Planning. Mrs. Francesca Yetunde Emmanuel was the only female Permanent Secretary (first in the Federal Ministry of Establishment and later Federal Ministry of Health). A number of women were appointed Commissioners in the states. In 1983, Ms Franca Afegbua became the only woman to be elected into the Senate. Also, very few women contested and won elections into the Local Government Councils during this time.

\section{Military Rule}

With the return of military rule in December 1983, the first formal quota system was introduced by the Federal Government as regards the appointment of women into governance. The Buhari administration directed that at least one female must be appointed a member of the Executive Council in every state. All the states complied with this directive; some states even had two or three female members. During the military regime of General Abdulsalami Abubakar (June 9, 1998 May 29, 1999), there were two women in the Federal 
Executive Council: Chief (Mrs) Onikepo Akande (Minister for Commerce) and Dr. 1araba Gambo Abdullahi (Minister of Women Affairs).

\section{The Third Republic}

In the 1990 elections into local governments heralding the Third Republic, very few women emerged as councilors and only one woman, Chief (Mrs) Titilayo Ajanaku, emerged as Chairperson of a Local Government Council in the West. During the gubernatorial elections, no female governor emerged in any of the states. Only two female Deputy Governors emerged, namely: Alhaja Sinatu Ojikutu of Lagos State and Mrs. Cecilia Ekpenyong of Cross River State. In the Senatorial election held in 1992, Mrs. Kofo Bucknor Akerele was the only woman who won a seat in the Senate. Very few women won election into the House of Representatives. One of these few was Chief (Mrs) Florence Ita Giwa who won in the Calabar Constituency under the banner of the National Republican Convention (NRC). Amongst the members of the Transitional Council appointed by President Babangida in January 1993, only two were women, namely Mrs. Emily Aig lmhokuede and Mrs. Laraba Dagash.

In the Interim National Government of Chief Ernest Shonekan, two female ministers were appointed into the Cabinet. General Abacha had some female Ministers at various times in his cabinet, including Chief (Mrs) Onikepo Akande and Ambassador Judith Attah.

\section{The Fourth Republic}

In the Fourth Republic which started on May 29, 1999, the Nigerian political terrain witnessed an increase in the number of women political appointees, even though women did not perform well at the elections. In the elections held before May 29, 1999, few women emerged as Chairpersons of local government councils. A number of women won elections as Councilors. Only Lagos State produced a female Deputy Governor in the person of Senator Bucknor Akerele.

In the National Assembly, there were only three women in the Senate, namely: Chief (Mrs.) Florence Ita Giwa representing Cross River State South Senatorial District; Mrs. Stella Omu from Delta State and Hajiya Khairat Abdul-Razaq (now Hajiya Gwadabe) representing the Federal Capital Territory. There were as at the time only 12 women In the House of Representatives and these are: Barrister lquo Minimah, Mrs. Patience Ogodo, Lola Abiola Edewor, Patricia 0. Etteh, Dorcas Odujinrin, J.F. Adeyemi, Binta Garba Koji, Gbemi Saraki, Florence Aya, Linda Ikpeazu, Temi Harrinnan and Mercy Alumona 1sei.

In the State House of Assembly, very few women emerged as members. While in some States, one or two women emerged in the Houses, most other states had virtually no females in their legislatures. States like Cross River, Akwa Ibom, Rivers, Lagos and many others did not have female members in their State Legislatures. 
Women are being appointed as Commissioners and therefore members of the Executive Councils in all the states, but while some states have one female, others have two females in the Executive Councils. The former President Olusegun Obasanjo appointed a number of women into the Federal Executive Council including: Dr. (Mrs.) Kema Chikwe (Minister of Transport), Mrs. Dupe Adelaja (Minister of State Defence), Dr. (Mrs.) Bekky Ketebuigwe (Minister of State, Ministry of Solid Minerals), Dr. (Mrs.) Amina Ndalolo (Minister of State, Federal Ministry of Health), Mrs. Pauline Tallen (Minister of State, Federal Ministry of Science and Technology), and Hajia Aishatu Ismaila (Minister of Women Affairs) and Chief (Mrs.) Titilayo Ajanaku Special Adviser to the President on Women Affairs.

From the foregoing, it is evident that only very few Nigerian women have participated and emerged in Nigeria's political landscape, in spite of the pioneering efforts of women like Funmilayo Ransome-Kuti and Margaret Ekpo since the $1950 \mathrm{~s}$.

\section{The Critical Role of Women in the Development of Nigerian Politics}

Over the years, women have been relegated to the background in issues of the overall development especially in the developing nations like Nigeria. Historical evidences are available to prove that the Nigerian women have for long been playing crucial role in political life of the country, and this has contributed in no small measure in shaping the political system of the nation. For development of any kind to be successful, a vantage position should be accorded the women, as they constitute larger proportion of the population. In this regard, they should not be left out in the issues of decision making that bothers even on their lives as a people.

Today, women are participating more actively in political issues than ever before as a result of political re-awakening and awareness. More often than not, they are besieged with challenges of which discrimination is rifer.

In 1957 during the pre-independence era of Nigeria, a couple of women political activists such as, Mrs. Margaret Ekpo, Mrs. Janet Mokelu and Ms. Young were members of the Eastern House of Assembly. The late Mrs. Funmilayo Ransome-Kuti, though not a full-fledged politician, was a very strong force to reckon with in the politics of the Western Region. This is because of her role in leading the women group at Alake's palace over women taxation. Importantly, Hajia Gambo Sawaba waged a fierce battle for the political and cultural emancipation of women in the North. It can be deduced from the foregoing that women have always played viable political roles in Nigeria in spite of all the limitations.

Infact, the Babangida era marked a turning point in the history of women struggle in Nigeria, when Maryam Babangida institutionalized the office of the first lady in 1987. She became the first working First Lady and launched the "Better Life for Rural Women" program. Other women who have made impact 
in the country's political scene include, Mrs. Ngozi Okonjo Iweala former Minister of Finance, Mrs. Obi Ezekwesili (former Finance Minister and Vice president of the World Bank), Late Prof. Dora Akunyili, the former NAFDAC boss also performed credibly by, among other things, leading the fight against adulterated pharmaceutical drugs.

Today, many countries of the world are making efforts to bridge the gap between men and women in politics. In Nigeria, efforts have been directed towards the political empowerment and participation of women. For example, the past administration clamour $35 \%$, affirmative action for women in the political arena however, the representation of women in Government even though has improved than before is still very low compared to what obtains in other nations of the world, particularly in the developed nations. Take for example the table below:

Table 1: Nigerian women in politics and their performance, 1999-2015

\begin{tabular}{|c|l|c|c|c|c|c|c|}
\hline S/N & Position & $\begin{array}{c}\text { No. of } \\
\text { seats }\end{array}$ & $\begin{array}{c}\text { No. of women } \\
\text { in 1999 }\end{array}$ & $\mathbf{2 0 0 3}$ & $\mathbf{2 0 0 7}$ & $\mathbf{2 0 1 1}$ & $\mathbf{2 0 1 5}$ \\
\hline 1 & Presidency & 2 & 0 & 0 & 0 & 0 & 0 \\
\hline 2 & Senate & 109 & 3 & 4 & 8 & 7 & 8 \\
\hline 3 & House of Reps & 360 & 12 & 23 & 26 & 26 & 14 \\
\hline 4 & Governorship & 36 & 0 & 0 & 0 & 0 & 0 \\
\hline 5 & D. governorship & 36 & 1 & 2 & 6 & 3 & 4 \\
\hline 6 & $\begin{array}{l}\text { House of } \\
\text { assembly }\end{array}$ & 990 & 12 & 38 & 54 & 62 & - \\
\hline & Total & 1533 & 28 & 67 & 94 & 98 & 26 \\
\hline
\end{tabular}

Source: Lance-Onyiewu, Maureen (2011), Excerpt from UN Women's Preliminary Analysis of the 2011 General Elections in Nigeria. 2015 column is computed with data from INEC ${ }^{\text {ee }} \mathrm{s}$ web site.

Table 1 shows a summary of the various political positions occupied by women between 1999 to 2015. The record unveils the fact that women still have a long way to go as their level of participation is still very low. A lot of factors can be adduced for this low level performance by women but the issue of political violence, money and godfatherism as well as the patriarchal nature of the Nigerian society cannot be ruled out. In fact, although Nigeria have been blessed with several female candidates aspiring to hold political offices but, the marginalization in all the country's democratization process still hold women's' political victory into political offices to much ransom. This tends to validate widespread concerns in spite of a national gender policy that was formulated to promote a $35 \%$ affirmative action for women in the political space (a policy that demands 35\% involvement of women in all governance process). The fact remains that women are grossly under-represented in the legislative and executive arms of government and are being short-changed in the political activities in the country. This increases much believe that women 
are not ripe enough to hold political offices. Meanwhile, women activists and groups in Nigeria had been since 1995, advocating for increase in the number of women in the political space, but very little has been achieved in this regard (Okechukwu, 2014).

Table 2: Current Representation of Men and Women in Elective Positions (2015)

\begin{tabular}{|l|l|c|c|c|}
\hline S/N & Position & Men & Women & Total \\
\hline 1 & President & 1 & 0 & 1 \\
\hline 2 & Vice President & 1 & 0 & 1 \\
\hline 3 & Senate & 101 & 8 & 109 \\
\hline 4 & House of Reps & 346 & 14 & 360 \\
\hline 5 & Governors & 36 & 0 & 36 \\
\hline 6 & Deputy Governors & 32 & 4 & 36 \\
\hline & Total & 517 & 26 & 543 \\
\hline
\end{tabular}

Source: Compiled with data from INEC website

Table 2 shows the current representation of men and women in elective positions as at year 2015. It represents the poor outing by women in the 2015 general elections which has become even more worrisome and disappointing because of the level of preparations carried out by a lot of women advocacy groups. Numerous seminars and conferences aimed at preparing the bulk of Nigerian women with political ambition for the electoral contest were also organised with both local and international participants. As part of the preparations, the Nigerian Women Interparty Forum was launched during one of such events in Lagos. The focus of the conference was "Redefining the Role of Nigerian Women in Political Life" held for female political leaders at the national and local levels from the six leading political parties and women legislators in the National Assembly. The Forum now offers a platform for women beyond the conferences to share experiences, network, advocate and lobby for political space for women within and outside the political parties (as discussed in the introductory segment). The necessity of this platform is to, "women should be empowered and encouraged to aspire for political leadership and governance positions, which is critical to societal and human development" (Olasupo, 2012). This is so because it is one thing to be empowered and a whole different thing to afterwards be encouraged with right words and complimentary actions to follow. The fact is that the 2015 general elections did not deviate from the pattern of previous elections although scholars, analysts and even women were optimistic that female aspirations in the political process will receive a boost from the amount of preparations undertaken in that direction. 


\section{Challenges of Nigerian Women in Politics}

The Challenges Nigeria women are faced with when it comes to vying for elective seats are both fundamental and manifold. Some of these problems are not peculiar to Nigeria but are rather widespread across the globe. While some countries have largely been able to overcome most of these problems, many others are still far from achieving tangible victory. These barriers are socioeconomic, ideological, political and psychological in nature (Human Rights Education and Monitoring Centre, EMC, 2014). These have been grouped into structural, Institutional and Cultural barriers (EMC, 2014).

\section{Structural Barriers}

Structural Challenges facing women in Nigeria (and by extension, some other countries around the world) include the level of socio-economic development of the nation and the career and professional status of women. The socioeconomic hindrances include unemployment, poverty, illiteracy and limited access to education, lack of sufficient financial resources, the dual role women play in the family and full time job and also, their choice of profession (EMC, 2014).

The poor economic stand of women has been explained as due to inadequate education, unemployment problems and lack of access to means of production. The influence of poverty on women hinders them from being politically active to the extent of being nominated for elective posts and scaling the hurdles to win an election. This is because the financial state of women is far behind that of men in Nigeria. Lack of funds/finances/financial support for Nigeria women in politics constitute a major barrier. While men have $65 \%$ financial Independence in Nigeria, women have only 35\%. For Instance, working women receive $20 \%$ less income than their male Counterpart (Nigeria Gender Report, 2012). Additionally, the Nigerian's myopic view of women in politics where few women at the forefront in politics are regarded as prostitutes is another important barrier. Also is the lack of support for political aspirations of women from husbands, where few men that support their wives' participation in politics are branded by the society as 'Mumu (dummy) or woman wrapper as the case may be has continually put women with genuine interest in holding political office at a disadvantage.

On the issue of the education of the girl-child in the country, (Fatile, Akhakpe, Igbokwe-Ibeto and Oteh, 2012) observes that times are now changing in favour of women but maintains that more needs to be done. According to these scholars, low level of education among Nigerian women makes them less exposed to and less knowledgeable about political issues. We however observe that although more needs to be done in this regard to increase the number of educated females. There are more highly educated women with strong career base in the country now than ever before. Many rural dwellers across the country are sending their female wards to school than it ever was. These few women should be allowed to have access to elective positions as a sign that the nation is willing to balance political power between women and 
men. It seems as if the society just find it difficult to place women in positions of authority where there are men capable of doing the same.

The dual roles women play in the family and a full-time job is another hindrance facing women in politics. Due to the patriarchal setting of the Nigerian Society, women have their husbands and children to care for fully as a matter of first priority. At times, they also have their parents and parents in law to cater for. To achieve this goal, they have much more domestic duties to perform compared to men. Also, they have formal or informal roles to as paid workers, traders or farmers. These take on so much of their time that little is left to invest in party activities that could help improve their chances of being nominated for elective positions (Fatile et al. 2012). According to EMC (2014) the unequal share of tasks in the home between men and women i.e. husband and wife makes it virtually impossible for women to be actively involved in politics.

Another critical barrier is lack of financial resources. For a woman to do well in Nigeria politics, she must be financially strong. If she has the finances that can beat that of the men, she is very likely to receive the necessary support. She can buy men over with money and get to the position she so desires. Besides this, Nigerians myopic view of women in politics is also an important barrier. This may be seen as an extension of patriarchy - where women who are in the forefront of politics are regarded as prostitutes. Also lack of support from husbands constitutes great barrier to women. Whereas, men who support their wives in their political aspirations are regarded as "mumu" "dummy" "woman wrapper" etc. the society has branded such men because of the patriarchal nature which is more peculiar to Nigeria.

\section{Institutional Barriers}

According to EMC report (2014), Institutional barrier is one of the fundamental barriers to women's involvement in active politics. It is in fact seen as the first cause of political inequality between women and men in any society. The manner, in which politics and political parties are structured especially in Nigeria and most developing countries, is such that women have limited chances to be well or adequately represented. The establishment and organization of the political arena are shaped around and it favour men than women (Lovenduski and Karam, 2002). According to these scholars, the present political arrangement is a product of long established political processes which were mainly male dominated. Men have always been at the helm of affairs; making and implementing policies. It is therefore easy to overlook and/or take lesser cognizance of women's issues and their possible involvement in years to come may not likely be looked into. Thus, it may not necessarily be a deliberate act (Lovenduski \& Karram, 2002) but that of an omission especially since Nigeria in a patriarchal society; women's interests and involvement in politics are subsumed in men's. This Institutional fault is 
foundational to women's under representation in elective posts because they were never part of the making of the rules and regulations guiding political activities in the country. Women are, so to say, late comers in the political scene.

\section{Cultural Barrier}

The Patriarchal system and its consequences especially as regards the traditionally held attitudes to women in decision-making positions is another fundamental problem facing women in politics. The Patriarchal system determines when a woman should enter politics, how she should go about it, the extent she is permitted to go and where she dares not venture into; else she'll meet with defeat.

There is still a very strong emphasis on women's roles as wives and mothers. A woman's roles in the family are seen as her primary reason for existence. The Patriarchal system has helped so much to subjugate and dominate women's abilities and capabilities in all spheres of life; Politics inclusive. For Instance, Patriarchy demands that women take permissions from their husbands and such be granted before they can join any political party or vie for position.

Also, a society's culture determines how women in politics are perceived. In Nigeria, women politicians are negatively perceived, they are seen by others and the media (even by other women) as women of easy virtue who are prone to promiscuity in a bid to get nominated and win election (EMC, 2014). Politics is also seen as a domain for women who have no husbands, whose husbands are former politicians and women who are single. All these perceptions pose challenges to women politicians and those intending to be (Lawal, 2015).

Some other challenges facing women in politics include the lack of the spirit of sisterhood among women to vote for their fellow women during elections at all levels (Fatile et al. 2012), the lack of confidence on the part of women to run in elections, the role of the media (EMC, 2014) and the division between private and public life by the society (Bari, 2005).

\section{International stand on Women in Politics}

The International community is keenly involved in advocating for more women in decision-making and governance generally. Having come to terms with the population of women in the world and their abilities to channel a better and/or added benefits to societies and the world at large, several International organizations are involved in getting more women representation in governance. One of the aims is to bring about a synergy between men and women in policy making and implementation for a better global development.

To this end, in 2003, the committee of Ministers of the council of Europe, for instance, recommended a $40 \%$ representation of men and women in all decision-making bodies in all its member States. One of its objectives is the protection of equal political and civic rights for men and women, (EMC, 2014). 
The United Nations has always advocate equality between men and women in all spheres of human life. It has its focus on getting more women into leadership positions in their various countries. It does this by supporting the member nations in setting standards geared towards gender equality (International Centre for Research on Women, 2012). This interest is also visible in the employment policy of most international non - governmental organizations; preference is given to qualified women and their non discriminatory policy is always on jobs advertisement pages. The outcome of the 1995 world conference in Beijin is another widely known effort towards a gender equal world.

\section{The Nigerian Affirmative Action Plan}

Affirmative action plan was coined in America in 1961 as a temporary action geared towards giving preferential treatment to individuals and groups within a society, who are disadvantaged minority or underrepresented in any sector of the economy due to past discriminations. India practiced it earlier in 1972 to increase parity in employment within the country. According to Stewart (2012), other countries like Brazil, Malaysia, Israel, South Africa etc. have this plan in their laws. This has been found to increase women's participation in politics in such countries.

The Nigerian Affirmative Action Plan was made to improve the participation of women in political and public life. It stipulates $35 \%$ representation of women in politics. The 2006 National Policy on women which should entrench and foster the implementation of the plan unfortunately lacks the necessary legal framework to enforce it (Ikpeze, 2011). Thus, the problem of implementing the plan in Nigeria is largely due to its lack of constitutionality. For example, the quota system of 1979 which deals with the issue of federal character was relatively well implemented because it has legal backing, as stipulated in the constitution of the country. Ikpeze (2011) argues that the Nigerian $35 \%$ affirmative action plan lacks constitutionality, which is needed to eliminating the discrepancies and fostering women's ability to lay claims to their human rights in this regard. He gives the example of South Africa where provision is given to Gender Equality Commission in its 1996 amended constitution. He further suggests that there is need for frequent evaluation and re-strategizing where necessary; considering the fact that affirmative actions have time limit i.e. are temporary measures to address past discriminations that have resulted in underrepresentation.

\section{Overcoming the Challenges of Women in Politics}

Having examined some of the barriers women are faced with in the Nigerian political environment, it is most important to examine how more women could be encouraged to go into politics and actively participate by vying for and winning more seats at all level of governance. This section examines how this 
could be achieved by looking at how some countries around the world have been able to achieve laudable feats in this respect and what Nigeria could learn from their successes.

According to Lovenduski and Karam (2002), four aspects of political processes need be changed to accommodate more women. These are:

i) Institutional or procedural change - this include cultural changes and greater gender awareness; which is a product of cultural change. There should be a continuous sensitization that both men and women are capable of ruling regard- less of their class, race or marital status

ii) Representation change - this has to do with action plans that are capable and strong enough to enhancing and securing women's continuous access to legislature. Women politicians should be encouraged by appointing them into executive positions within the parties and the party structure should compulsorily be made gender sensitive with a purposive plan to place women in crucial political positions. All the major political parties in Nigeria as of today, do not have women in key executive positions. At the very best, women are made women leaders within the parties.

iii) Impact on Output - According to these scholars, laws and policies on women should be on the agenda of any policy making

iv) Discourse change - Legislations should be used to change public opinions of women politicians. They should be viewed in the same way men are viewed in terms of rationality and intelligence.

Human Rights Education and Monitoring Centre, EMC (2014) divides political participation to three parts, namely: the right to choose political leaders, the right to be chosen as a political leader and a gender - sensitive policy making and implementation mechanisms. The last two shall be dealt with here. In order to get more women elected during elections, EMC made several workable recommendations. They are examined in the following pages.

i. Legislation - There is need for a constitutional amendment or review where women's rights issues are strongly entrenched and discriminatory clauses removed. Some scholars have argued that such reforms may not necessarily be practiced in reality as it should except a constitutional backing is in place to enhance the struggle for its implementation in real life (Ikpeze, 2011). This is because when such cases are taken to the law court, the constitution can be used as a tool to achieving justice. Rwanda's constitution is a model in this regard; right from its introduction, it entrenches equality and specifically ensures equality between the sexes and prohibits gender discrimination. Rwanda and Uganda prohibit political discrimination against women and also laid solid foundation for gender quotes in political parties. Today Rwanda has the highest percentage of women in political positions in the world.

ii. Political Party's Management Style - The political parties have duties to perform in order to help women gain ground in politics. Women should 
be integrated into the party management. Political parties need to have constitutions that are gender sensitive and guarantee women's adequate representation. For example, in Nordic countries with the highest number of women in governance in Europe, political parties adopt quotas to ensure a certain percentage of political seats are reserved for women. Norway for example, since 1989 has always had a 40\% quotas for both men and women in all its elections and political nominations. So, in Nigeria the target of any such quota should be on the number of women who eventually win elective seats and not those who are aspirants or candidates. INEC for instance can give certain incentives to parties that have up to $40 \%$ women in elective posts. All the political parties in Nigeria need some forms of internal reforms that encourage transparency, accountability and destroy all resistance to women's leadership. Party leaders as it is now have a lot to do in this respect. It therefore means that men are integral to the achievement of gender equality in politics.EMC gave an example of the Liberal Democrats, in the United Kingdom that went all out to increase the number of women in the nation's parliament by addressing the issue of cash, confidence and culture. They solved the obstacle of lack of access to finance by intending female candidates by establishing a trust fund to help meet their personal costs of campaigning, travel cost and child/elder care costs. To solve the problem of lack of confidence to vie for elective posts, a program was initiated where female politicians holding elective positions were asked what there experiences were and the demand of political culture. The result was used to organize training for women on public speaking, answering hostile questions and debates. Also, an awareness raising program was organized at the local level for skills acquisition and recruitment of spokeswomen and female candidates.

iii. Gender Quotas - This is an effective means of achieving gender equality in politics within a very short period. EMC analyses three major types of quotas in use:

(a) Reserved seats

(b)Political party quotes and

(c) Legal candidate quotes

The reserved seats ensure that certain percentages of political seats are reserved exclusively for women. Political and legal candidate quotas stipulate a minimum number of women that are candidates for elections in political parties candidate lists. Rwanda used electoral gender quotas to achieve a gender - balanced parliaments (EMC, 2014). A three ballot system was used in 2001 and 2006 to enhance women's victory in local elections. All voters were to cast their votes into three boxes, one general box, a women's ballot box and a youth's ballot box. All voters are to vote 
for a candidate for each of the boxes. This is to make people get used to voting for women and increase female elected politicians at the local government level. The doctrine of the Affirmative Action and CEDAW should be strengthened so that they could have considerable impacts on the political landscape of Nigeria thereby curtailing any form of discrimination against women.

In Spain and Belgium, a political party's candidate lists would be rejected if the minimum gender quote is not met. In Israel, a one -third women to men's presence on the board of directors was implemented in both private and public organizations, just to bring women to the limelight. This was also adopted in Belgium in 2011 and defaulting organizations are made to pay fines. The federal government of Nigeria can borrow a leaf from these advanced countries by making make it mandatory for certain public offices be allotted to women on equal basis. This will dissolve any form of discrimination of women by men especially in the political arena.

iv. Gender- Friendly Budgeting (GFB) or Gender - Responsive Budgeting (GRB) Respond to the gender difference in society by allocating money to implement gender policies and programs with the aim of striking a balance between the interests of both men and women; thus, moving the society towards gender equality. In this way, the government is committed to achieving gender equality. Countries that adopted GRB include South Africa Austria and Uganda etc. Uganda uses GRB under the Forum for Women in Democracy (FOWODE) to initiate training for women councilors so that they could be adequately equipped to represent women's interest at the local government level.

v. Youth Programmes - Organising youth programs are effective ways of preparing the minds of young people especially women for future leadership roles. This kind of program helps to debunk the learnt cultural attitudes that stand as obstacles to women's leadership and involvement in decision - making from the minds of the upcoming generation.

vi. There is also a need for intending female politicians to be trained on how to campaign i.e. campaign skills. EMC (2014) identifies a Bahrain women who became the first woman to win an election after she took part in a campaign skills training. Such training programs could help increase women's confidence, political knowledge and skills.

vii. The obstacle due to women's dual roles could be ameliorated through a more family - friendly political arena. For example, Austria had to change its legislative hours for the house of representative in such a way that all forms of sittings end latest at $9 \mathrm{pm}$. Also, a crèche was established within the building of the parliament to cater for female politicians with young children. Also in Norway, all day care center are heavily subsidized to alleviate the burden of child care on women. In fact it is the second best country in the world to be a mother (EMC, 2014). 
viii. Many countries around the world have also established and /or encouraged the establishment of women's parliamentary caucuses. They function to enhance women's push for the actualization of their interests. The Forum of Women Parliaments, comprising of women politicians across parties and ethnic groups were established. They all work together to achieve gender - friendly legislations. In the same vein, women's caucuses group was able to succeed in advocating for the elimination of sexist languages in public administration in Argentina. Also a women caucuses group in Uruguay assisted in the establishment of gender Equity committee which is advocating for certain women's human rights in the country. In Brazil, a similar group joined force with other women groups to advocate for protective laws against violent act on women and reproductive health.

Some of these strategies as identified by EMC (2014) could be adopted successfully in Nigeria if we are ever serious about achieving gender equality and increasing both the presence and impact of women in decision making. Some other scholars have also contributed their voices to finding lasting solutions to the many challenges facing Nigerian women in politics. The following are some of their recommendations

i. Ikpeze (2011) maintains that women need to take their destinies in their hands by advocating strongly for the legislation of their right to governance. He argues that such does not come easily except a level of force is applied.

ii. Men need to view the world in terms of having equality with women in order to achieve any tangible development in the country (Ikpeze, 2011).

iii. Women in Nigeria need to also trust their follow women to the extent of voting them in whenever they vie in elections. For example, if all registered Nigeria women had voted for Prof. Remi Sonaiya in the 2015 general elections, she would likely have had a very high chance of winning the presidential seat.

iv. There should be structures put in place such as the legal funds. These structures will enable women politicians challenge any form of electoral malpractice in Nigerian political terrain.

v. Experienced female politicians need to mentor other women who are interested in entering politics (Irabor, 2011).

vi. To change the all generation standing order of women discrimination and domination by men, we opine that gender education need to be inculcated into the nation's education curricula at all levels. The subject or course (as applicable) should be made compulsory from primary to the university for both male and female pupils/students. 


\section{Theoretical Framework}

A theory is a system of related ideas that enable one to explain and predict phenomena. The pivotal role of theory in research is very important and cannot be overemphasized. According to Ola (1983), "a theory is like a map which guides a research from unknown destination to a known destination". It is against this premise that a relevant sociological theory which explain the concept of women in political activities examined with a view to guiding and providing deeper insights into the subject matter of this enquiry. Thus, Liberal feminist theory serves as the guiding theoretical framework for this study.

Liberal feminism claims that gender differences are not based in biology, and therefore that women and men are not all that different -- their common humanity supersedes their procreative differentiation. If women and men are not different, then they should not be treated differently under the law. Women should have the same rights as men and the same educational and work opportunities. Politically, liberal feminist activities focus has been concerned with visible sources of gender discrimination, such as gendered job markets and inequitable wage scales, and with getting women into positions of authority in the professions, government, and cultural institutions. Liberal feminist politics took important weapons of the civil rights movement antidiscrimination legislation and affirmative action -- and used them to fight gender inequality, especially in the job market.

\section{Conclusion}

This paper has attempted to examine the need for women to be involved in politics in Nigeria; especially as elected leaders at all levels of governance. The challenges confronting women that need to be addressed as a matter of urgency were examined. Suggested solutions drawn across nations and scholars were discussed. The future of Nigeria women in politics is bright if only these challenges are objectively and effectively addressed. However, it should be bore in mind that increasing women participation and election is not all that matter. Rather, effort should be made to ensure the presence of women is felt by allowing them to influence decisions that are crucial to their existence and that of the whole nation in elected positions. Women should also take their destiny in their hands by voting, vying for elective posts and speaking out for change; According to Mclosky (in Eme, Onyishi \& Nwaoha, 2014), 'in a democracy, participation is power'. Women need to consider this statement, make up their minds, to form a united front and advocate for their human rights because women's rights are human rights.

\section{Recommendations}

(i) There should be equality in the sharing of political offices on the basis of quota system between competing candidates. This will enable both men and women of having equal chances of control in such public offices. 
(ii) The federal government should make it mandatory that certain public offices be allotted to women on equal basis. This will dissolve any form of discrimination of women by men.

(iii) Money politics should be discouraged in Nigeria while women who want to take active part in politics be encouraged to do so without any fear or favour.

(iv) The doctrine of the Affirmative Action and CEDAW should be strengthened so that they could have considerable impacts on the political landscape of Nigeria thereby curtailing any form of discrimination against women.

(v) There should be structures put in place such as the legal funds. These structures will enable women politicians challenge any form of electoral malpractice in Nigerian political terrain.

(vi) There is no doubt that women have some potentials and rights to contribute meaningfully to the development of their country. Therefore, the Nigerian government should work towards achieving gender equality in democratic governance, increase women participation and access to politics. It must be realized that the role of women as home makers can not be down played in that it equally has an extended impact on their responsibility in service, the women touch anywhere cannot be matched.

\section{References}

Agbalajobi, D.T. (2010) 'Women's Participation and the Political Process in Nigeria: Problems and Prospects', African Journal of Political Science and International Relations, 4(2): 75-82.

Aliyu, B.N. (2009) "The Dynamics of Sexual politics in Nigeria: A Catalyst for Gender Bias". Journal of Emerging Trend in Educational Research and Policy Studies, 2(6): 471-478.

Bari, F. (2005) Women's Political Participation: Issues and Challenges. Online Retrieved on February 13, 2015 from www.un.org/--/EGM-WPDEE-2005.EP.12\%20\%20draft\%20F.pdf.

Cheng, C. (2014) Why we need more Women in Parliament Online. Retrieved on February 13, 2015 from https://christiness.ottcheng.wordpress.com/-/women---politics/---women.

Dike, P. Chike E. (1995) The Women's Revolt of 1929. Lagos: N.G.A.

Ekine, S. (2013) "Nigeria @ 50: What about the Women?" New Internationalist Blog.

Eme, O.I., Onyishi, T., Nwaoha, C. (2014) Women and Politics in Nigeria: Strategising for 2015 from www.arabianjbmr.com/pdfs/KD_Vol3_/2/1.pdf.

EMC (2014) Women and Political Representation: Handbook on increasing Women's Political Participation in Georgia. Retrieved on August 18, 2015 
from www.coe,int/E/democracy/electoralassistance/publications/Handbook-women-Georgia -en.pdf.

Falobi, F. (2015) Marginalisation of Nigeria Women in Politics. Online.dailyindependencenig.com/2015/---/marginalization-Nigeria-women-politics.

Fatile, O.J., Akhakpe, I., Igbokwe-Ibeto, C.J., Oteh, C.O. (2012) Feminism and political participation in Nigeria: An Empirical Analysis. Online Retrieved on February 13, 2015 from www.aessweb.com/download.php?id $=1366$.

Ikpeze (2011) Understanding Affirmative Action as Aid to Women Human Rights in Nigeria. Online Retrieved on February 14, 2015 from www. Ajol.info/index.php/nauji/j/article/download/82399/72553.

Irabor, F.O. (2015) Reviewing Women's Participation and Performance at the 2011 General Elections in Nigeria. Retrieved on February 13, 2015 from baob abwomen.blogspot.com/.../reviewing-women-parites pation-and.htm

Lawal, S. (2015) Breaking Gubernatorial Barriers for Women. Retrieved on February 13, 2015 from nationalmirroronline.net/.../2015-breakinggubernatorial-barriersfro-women.

Lovenduski, J. and Karram, A. (2002) Women in Parliament: Making a difference. Online. Retrieved on February 14, 2015 from www.idea.nt/publications/WIP/upload/4\%20-karam.pdf.

Lance, O.M. (2011) Excerpt from UN Women's Preliminary Analysis of the 2011 General Elections in Nigeria. 2015 column is computed with data from INEC ${ }^{\text {ee }} \mathrm{s}$ web site.

Miranda, R.L. (2005) Impact of Women's Participation and leadership on outcomes. Retrieved on February 18, 2015 from www.iisd.ca/4wcw/dpa053.html.

Okechukwu, J. (2014) "Perspectives on Critical Impediments to women in Decision-making process" in Clara, O. and Nina, M. (eds.), Nigerian Women in Politics (1986-1993).

Ola, B.N. (2008) "The Dynamics of Sexual politics in Nigeria: A Catalyst for Gender Bias". Journal of Emerging Trend in Educational Research and Policy Studies, 2(6): 471-47.

Olasupo, G.A. (2012) 'Nigerian Women in Politics: A study of the Role of Women in President Obasanjo's Administration 1999-2003' in Falola, T. et al. (eds.) African Women and Cultural Affairs. Lagos: Dalton press.

Omu, R. and Makinwa T. (2008) Women Political Participation in Nigeria: Problems and Prospects in Akinboye, S.O. (eds.) (2010). Paradox of Gender Equality in Nigerian Politics; Lagos: Concept publications.

Paddock, T., Adam, F. and Toyin, F. (2011) The Women's War of 1929: A History of Anti- Colonial Resistance in Eastern Nigeria. Durnham, NC: Carolina Academic Press.

Soraya, C. (2012) Women in Politics: Why we need more Women in Office. Online. Retrieved on February 13, 2015 from www.huffingtonpost.com/soraya---/women-in-politics-b-130.7586.html. 
Tor, J.T. and Terkula, G. (2011) "Women on Edge: Interrogating Gender and Governance in Nigeria's Fourth Republics". Nigerian Journal of Politics and Administrative Studies, 2(2). 